\title{
Microbial diversity and anaerobic hydrocarbon degradation potential in an oil-contaminated mangrove sediment
}

\author{
Luiza L Andrade ${ }^{1,3}$, Deborah CA Leite ${ }^{1}$, Edir M Ferreira ${ }^{1}$, Lívia Q Ferreira ${ }^{2}$, Geraldo R Paula ${ }^{2}$, Michael J Maguire ${ }^{3}$, \\ Casey RJ Hubert ${ }^{3}$, Raquel S Peixoto ${ }^{1}$, Regina MCP Domingues ${ }^{2}$ and Alexandre S Rosado ${ }^{1 *}$
}

\begin{abstract}
Background: Mangrove forests are coastal wetlands that provide vital ecosystem services and serve as barriers against natural disasters like tsunamis, hurricanes and tropical storms. Mangroves harbour a large diversity of organisms, including microorganisms with important roles in nutrient cycling and availability. Due to tidal influence, mangroves are sites where crude oil from spills farther away can accumulate. The relationship between mangrove bacterial diversity and oil degradation in mangrove sediments remains poorly understood.

Results: Mangrove sediment was sampled from 0-5, 15-20 and 35-40 cm depth intervals from the Suruí River mangrove (Rio de Janeiro, Brazil), which has a history of oil contamination. DGGE fingerprinting for bamA, dsr and $16 \mathrm{~S}$ rRNA encoding fragment genes, and qPCR analysis using $d s r$ and 165 rRNA gene fragment revealed differences with sediment depth.

Conclusions: Analysis of bacterial $16 \mathrm{~S}$ rRNA gene diversity revealed changes with depth. DGGE for bamA and dsr genes shows that the anaerobic hydrocarbon-degrading community profile also changed between 5 and $15 \mathrm{~cm}$ depth, and is similar in the two deeper sediments, indicating that below $15 \mathrm{~cm}$ the anaerobic

hydrocarbon-degrading community appears to be well established and homogeneous in this mangrove sediment. qPCR analysis revealed differences with sediment depth, with general bacterial abundance in the top layer $(0-5 \mathrm{~cm})$ being greater than in both deeper sediment layers (15-20 and 35-40 cm), which were similar to each other.
\end{abstract}

Keywords: Mangrove, Bacterial diversity, Anoxic sediment, Sulphate, Petroleum, Hydrocarbons

\section{Background}

The Deepwater Horizon oil spill of 2010 in Gulf of Mexico serves as a reminder of the potential adverse impacts of petroleum compounds to the environment $[1,2]$. Petroleum is a complex mixture of saturated and aromatic hydrocarbons, polar compounds, resins and asphaltenes. Saturates are proportionally the most significant fraction by mass while the most toxic and persistent compounds are the polar and aromatic hydrocarbons [3]. Such compounds can be responsible for massive wildlife death soon after oil spills and, as well as over the medium and longterm [1]. Unfortunately, accidents resulting in oil spills

\footnotetext{
* Correspondence: asrosado@micro.ufrj.br

'Laboratório de Ecologia Molecular Microbiana, Instituto de Microbiologia Paulo de Góes, Universidade Federal do Rio de Janeiro, Rio de Janeiro, Brazil Full list of author information is available at the end of the article
}

happen routinely, and due to tidal activity spilled oil is commonly transported to coastal regions. In temperate to tropical latitudes mangrove forests are one of the ecosystems that are most detrimentally affected [4].

Mangroves are vital ecosystems for coastal protection. Their features make them a unique environment, with high biological diversity and activity. Salinity and organic matter availability vary in different parts of mangrove forests [5]. Beneath a thin aerobic surface layer, mangrove sediments are predominantly anaerobic, i.e., anaerobic biochemical processes are catalyzed by sediment microbial communities [6]. In previous studies about microbial populations, it was shown that Alphaproteobacteria dominated the bacterial community in a non-disturbed Brazilian mangrove sediment [5] and that after crude oil exposure, bacterial groups such

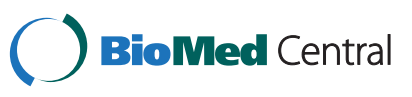


as Anaerolinea decrease in population abundance whereas Deltaproteobacteria increase [7]. The anoxic nature of mangrove sediment is a key feature that allows oil accumulation in such ecosystems [8]. For example, after an oil spill it is possible to detect higher amounts of oil in deeper sediment than at the surface, showing that oil tends to percolate through the sediment down to deeper layers $[9,10]$.

Several microorganisms are capable of degrading aliphatic and aromatic hydrocarbons under anoxic conditions [11]. Boopathy [12] studied diesel degradation in estuarine sediment microcosms in the presence of different terminal electron acceptors. In the presence of nitrate, sulphate and carbonate, $99 \%$ of the crude oil was removed within 510 days, whereas stimulating only sulphate reduction, methanogenesis, or nitrate reduction resulted in 62,43 , and $40 \%$ oil removal, respectively. Boopathy and colleagues observed the same interesting results on anaerobic oil hydrocarbon degradation in follow-up studies, showing that sulphate-reducing condition is the most efficient redox condition in experiments using individual electron acceptors $[13,14]$.

Petroleum hydrocarbon degradation pathways are distinct. It is believed that n-alkane-utilizing strains do not grow with aromatic hydrocarbons, and vice versa [15]. There are two elucidated mechanisms for anaerobic alkane degradation. One involves fumarate addition to the alkane subterminal carbon to produce alkylsuccinate compounds, and in the other process the alkane is carboxylated [16]. The enzymes responsible for fumarate addition in anaerobic alkane metabolism are alkylsuccinate synthases, AssA1 and AssA2, encoded by assA1 and ass 2 genes, respectively $[17,18]$.

Aromatic hydrocarbons are converted to a few central intermediates before being further metabolized. The most common central intermediate of the anaerobic aromatic hydrocarbon transformation is benzoyl-CoA [19], which is then converted to dienoyl-CoA. The next set of reactions ends with a 6-OCH-hydrolase enzyme opening the aromatic ring of the compound. This enzyme is encoded by $\operatorname{bam} A$ which is considered as a good genetic marker for studying anaerobic aromatic hydrocarbon degradation, since it contains highly conserved regions [20]. However, bamA is involved in anaerobic aromatic hydrocarbon degradation in general, and not exclusively degradation of petroleum-derived compounds. Another good target for the detection of anaerobic aromatic hydrocarbon-degrading microorganisms is the enzyme benzylsuccinate synthase (Bss), which is involved in the anaerobic degradation of toluene and xylene, via fumarate addition to the methyl group, transforming these compounds into benzylsuccinates. Bss has been identified in all anaerobic toluene-degrading microorganisms studied to date, and is composed by three subunits, of which, $\alpha$ subunit, encoded by bss $A$ gene is the target for molecular studies. This gene is highly conserved and has been employed as a molecular marker for the characterization of environmental samples [20-22].

Despite the importance of crude oil pollution in coastal environments, little attention has been paid to bacterial diversity and anaerobic degradation potential of crude oil hydrocarbons in mangrove sediments. Therefore, the aims of this study were: to compare microbial community profiles in sediments from different depths; to quantify total bacteria and sulphate-reducing bacteria (SRB) as a function of depth; and to screen for the presence of key genes involved in anaerobic hydrocarbon degradation in mangrove sediment.

\section{Results}

\section{Sediment porewater sulphate concentration}

In the current study, sulphate was measured at each studied depth, and in the surface sediment $(0-5 \mathrm{~cm}$ layer), its concentration was $14.9 \mathrm{mM}$. Sediment from the two other studied depths, $15-20 \mathrm{~cm}$ and $35-40 \mathrm{~cm}$, had a sulphate concentration of $3.6 \mathrm{mM}$. This suggests an active sulphate reduction zone in the top $15 \mathrm{~cm}$ of the sediment. These values reflect the influence of seawater ( $28 \mathrm{mM}$ sulfate) in mangrove ecosystems, which is introduced by tidal activity.

\section{Sediment microbial community analyses: PCR-DGGE for $16 \mathrm{~S}$ rRNA, bamA and dsr genes}

To study the bacterial community profile, genomic DNA extracted from sediment samples was analysed by PCR using universal primers to amplify $16 \mathrm{~S}$ rRNA gene fragments. Amplicons with the expected size of $430 \mathrm{~kb}$ were separated by denaturing gradient gel electrophoresis (DGGE) and the results showed a clear distribution of the bacterial populations within the three studied depths (Figure 1), revealing the occurrence of two main clusters: one cluster from the $0-5 \mathrm{~cm}$ layer, and another associated with sediment samples from both 15-20 and 35-40 $\mathrm{cm}$ depth.

To study the SRB community at different sediment depths PCR-DGGE was performed using primers targeting the $d s r$ gene that encodes the dissimilatory bisulphite reductase enzyme that is present in all sulphate reducers [23]. This revealed the occurrence of two main clusters, one cluster derived from the $0-5 \mathrm{~cm}$ sediment and the other was associated with sediment samples from both 15-20 and 35-40 cm depth (Figure 2).

PCR-DGGE using primers targeting the $\operatorname{bamA}$ gene, responsible for anaerobic aromatic hydrocarbon degradation, revealed a distribution of two main clusters. Unlike the $16 \mathrm{~S}$ rRNA gene and $d s r A B$ patterns, bam $A$ distributions were revealed by one distinct banding pattern common to both the $0-5$ and $15-20 \mathrm{~cm}$ depths, and a 


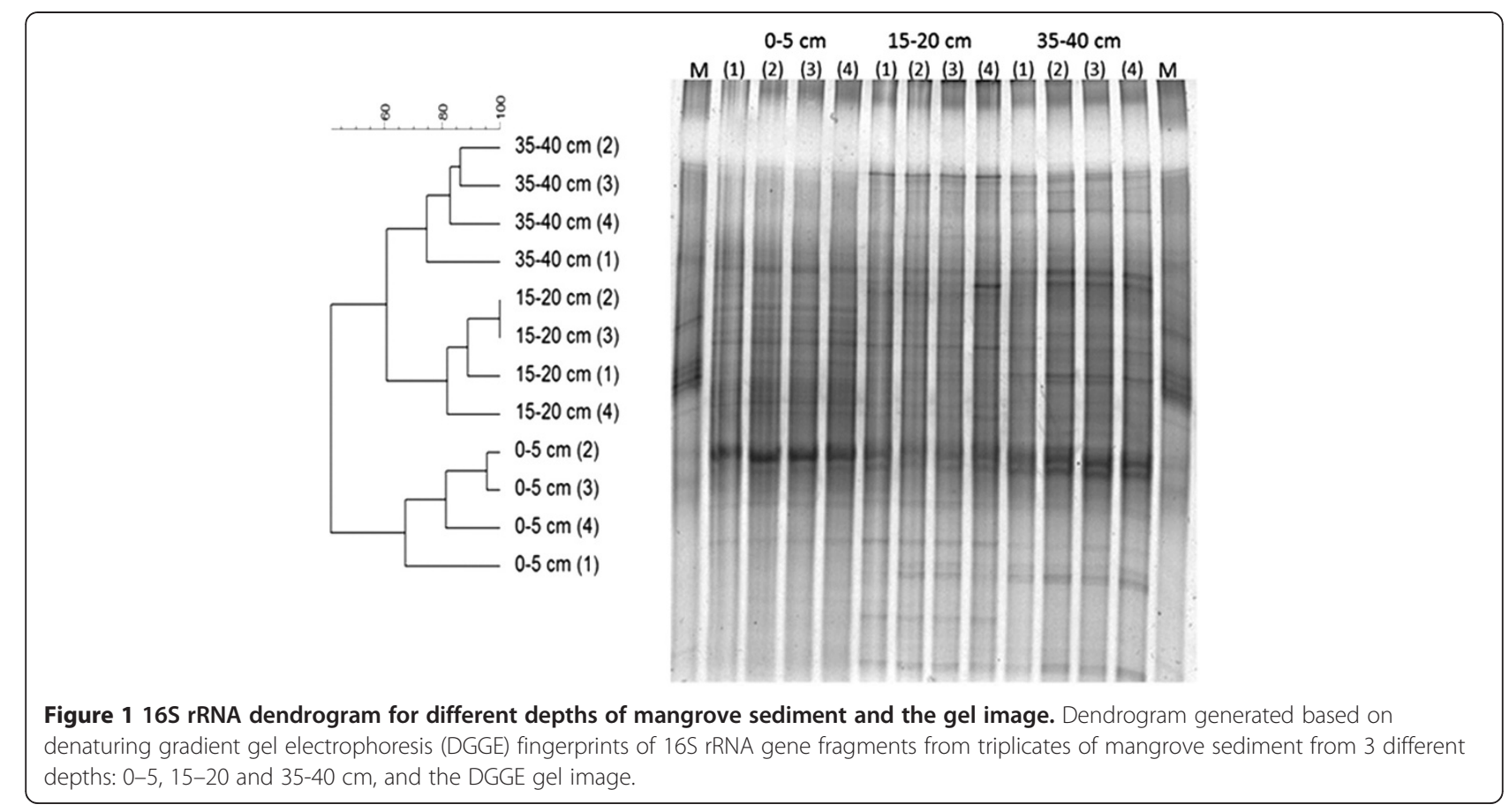

different pattern in the deeper 35-40 cm sediment (Figure 3). The patterns in the shallower sediments can further be clustered specifically to the $0-5$ and $15-20 \mathrm{~cm}$ sediment depths.

Molecular techniques for sediment: PCR for ass $A$ and $b s s A$ To further verify the potential for anaerobic petroleum hydrocarbon degradation within the sediment microbial populations, end-point PCR analyses targeting ass $A$ and bss $A$ genes were performed. Genomic DNA from all three sediment depths did not give rise to a PCR product using these primers, despite the fact that this mangrove sediment has a history of petroleum contamination.

\section{Molecular techniques for sediment: q-PCR for 16S rRNA and $d s r$ genes}

To estimate the bacterial abundance within the three depth horizons, a quantitative (q-) PCR assay was performed for $16 \mathrm{~S}$ rRNA genes using sediment genomic DNA samples as templates. Results presented in Figure 4a show depth variations of total bacterial $16 \mathrm{~S}$

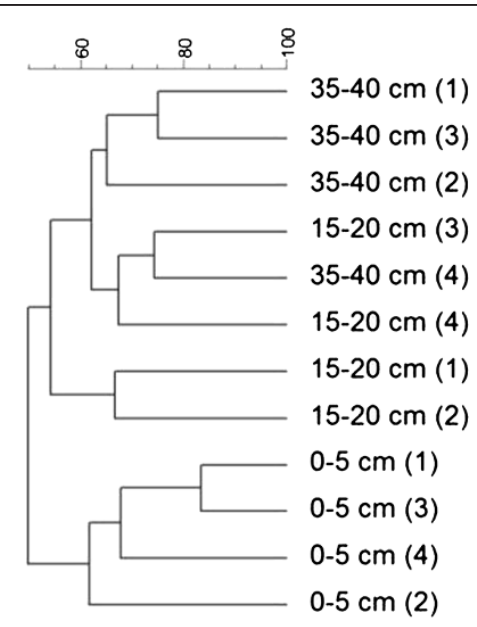

$0-5 \mathrm{~cm} \quad 15-20 \mathrm{~cm} \quad 35-40 \mathrm{~cm}$

(1) (2) (3) (4) (1) (2) (3) (4) (1) (2) (3) (4)

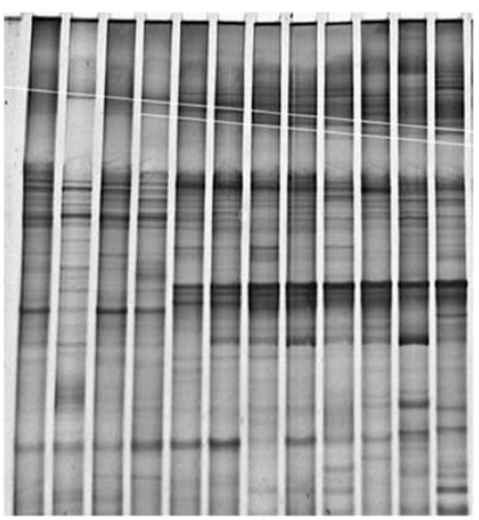

Figure $2 d s r$ gene dendrogram and gel image for different depths of mangrove sediment. Dendrogram generated based on denaturing gradient gel electrophoresis (DGGE) fingerprints of $d s r$ gene from triplicates of mangrove sediment from 3 different depths: 0-5, 15-20 and 35$40 \mathrm{~cm}$, and the gel image. 


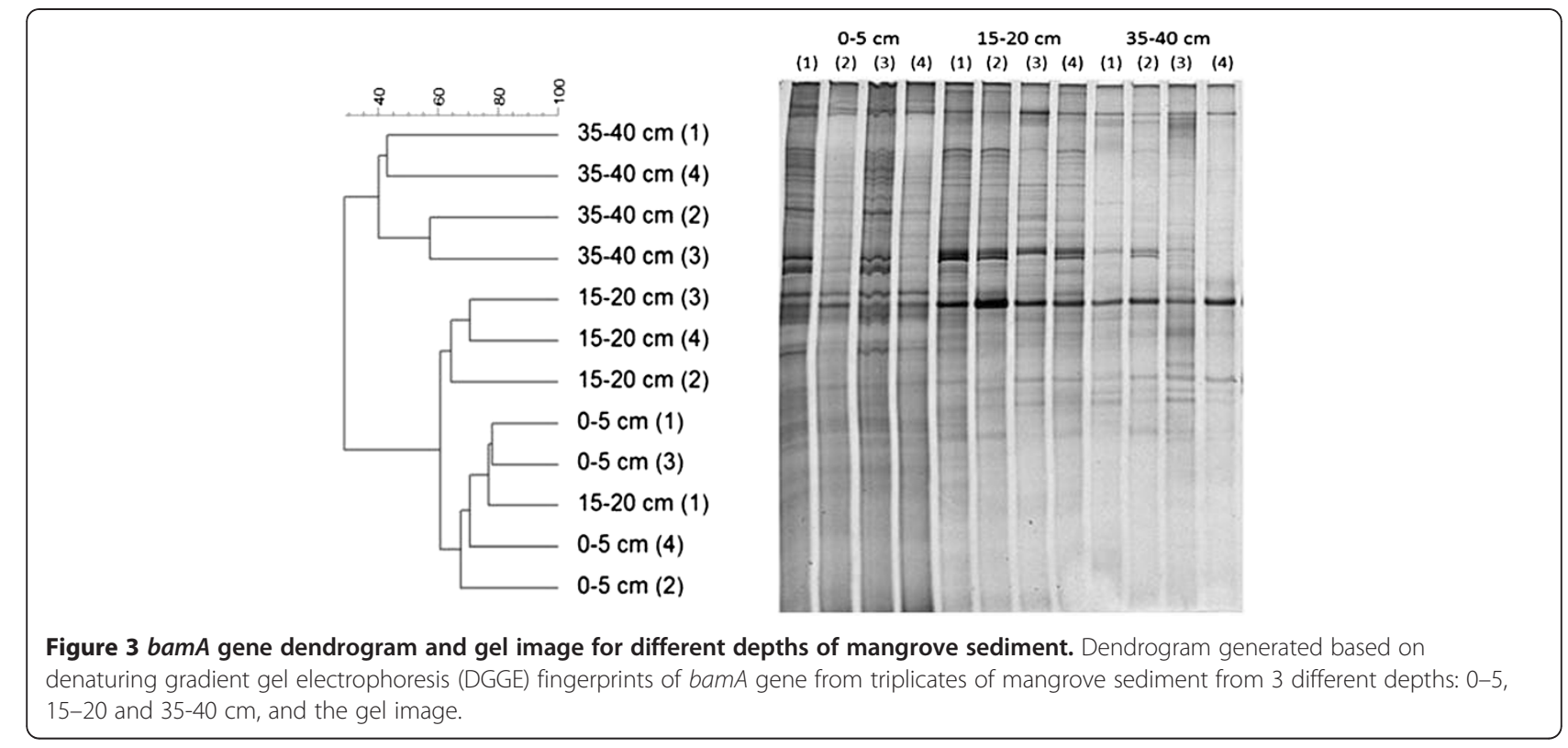

rRNA genes. In the top sediment, q-PCR detected $4.6 \times 10^{8}$ genes $/ g$ of sediment, in the middle layer, $1.78 \times 10^{8}$ genes/g of sediment, and in the deep sediment, the abundance was $3.2 \times 10^{7}$ genes/g of sediment. One-way ANOVA indicated that the only significant difference was detected between the $0-5$ and the $35-40 \mathrm{~cm}$ layers.

In order to estimate the abundance of SRB in the sediment samples, q-PCR was performed for $d s r$. The results were used to compare SRB abundance as a function of sediment depth and are shown in Figure $4 \mathrm{~b}$. In the top sediment, q-PCR detected $3.6 \times$ $10^{8}$ genes/g of sediment, in the middle layer $6.6 \times$ $10^{7}$ genes/g of sediment were detected, and in the deeper layer the abundance was $2.1 \times 10^{7}$ genes/g of sediment. As such, SRB abundance decreases with depth, with one-way ANOVA confirming that the abundance in the surface sediment is significantly different from the abundance in the two deeper layers.

\section{Discussion}

Pore-water sulphate concentration decreases from 14.9 to $3.6 \mathrm{mM}$ in the top centimeters and remains low in the deeper sediment, indicating a near-surface sulphate reduction zone, as observed elsewhere [24-29]. Sulphate concentration in seawater and marine sediments is around $28 \mathrm{mM}$ [11]. Mangroves are brackish ecosystems, due to tidal activity, and have a higher sulphate concentration than freshwater sediments.

In accordance with the sulphate profile, q-PCR showed a significantly larger population of $d s r$-containing microorganisms in the $0-5 \mathrm{~cm}$ layer relative to the deeper sediments. This is consistent with the sulphate-reduction zone being located in the shallower sediment interval and suggests that SRB populations are active there. High microbial abundance in the shallow sulphate-containing sediment was also reported in previous studies [28], where it was associated with intense sulphate reducing activity likely owing to organic matter availability.
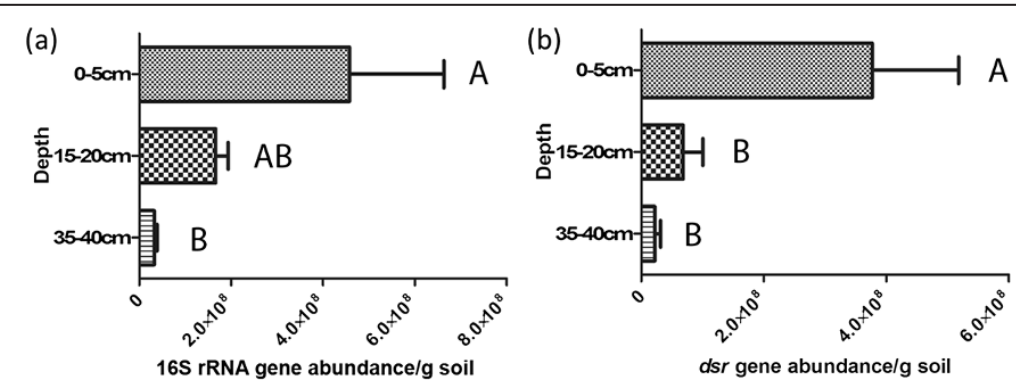

Figure 4 Bacterial abundance at different depths of mangrove sediment. Abundance of bacterial populations on mangrove sediments of three different depths tested with q-PCR using oligonucleotide primers for 165 rRNA gene encoding fragment (a) and oligonucleotide primers for dsr gene (b). Bars with the same letter are not significantly different (one-way ANOVA). 
DGGE was used to assess the sediment bacterial community, using as targets the genes encoding $16 \mathrm{~S}$ rRNA, BamA and DsrAB. DGGE analysis of $16 \mathrm{~S}$ rRNA gene diversity revealed depth-dependent differences. A distinct bacterial community composition was identified below $5 \mathrm{~cm}$ (i.e., below the sulphatereduction zone) and is similar in the two deeper sediments, possibly due to lower organic matter availability.

Positive PCR amplification of $\operatorname{bamA}$ indicates the potential for anaerobic aromatic hydrocarbondegrading microorganisms at all sediment depths. BamA is involved in the degradation of aromatic hydrocarbons in general, not only petroleum-derived aromatics. BamA-encoding microorganisms are found in the environment independently of contamination $[20,30]$. Plant matter is a major source of aromatic hydrocarbons [31], which may explain the prevalence of BamA-encoding microorganisms throughout the sediment. Alternatively spilled crude oil percolates deep into the sediment, and the close contact with aromatic compounds in more recalcitrant crude oil fractions might enrich $\operatorname{bam} A$ containing microorganisms. The apparent absence of Bss-encoding bacteria might be explained because the $b s s A$ variants targeted by our PCR primers may be mainly involved in anaerobic degradation volatile aromatic compounds (e.g., toluene and o-xylene [22]) which evaporate soon after the oil is spilled. Alternatively, other metabolic pathways and functional genes could be involved in the degradation of oil-derived aromatics in this mangrove sediment. The DGGE analysis of $\operatorname{bamA}$ diversity showed that the population structure of aromatic hydrocarbon degrading bacteria also changes with depth, being more similar in the top $20 \mathrm{~cm}$, where the influence of plant detritus is greatest. In deeper sediment, 35-40 cm, the DGGE pattern contains fewer bands than the other two analyzed depths.

Küntze and colleagues [20] recommended the combination of PCR for $\operatorname{bamA}$, which gives an overview of the anaerobic aromatic hydrocarbons degrading microorganisms present in the studied material, with PCR for bss A, which is specific for toluene and xylene degradation - although this gene also seems to be involved in the degradation of some long-chain aromatic hydrocarbons (L. Andrade, unpublished data). In the current study, sediment samples from the three depths tested negative for $b s s A$ (data not shown). Samples were also similarly screened with PCR primers targeting ass $A$, involved in anaerobic alkane degradation, and results were also negative. Our failure to amplify $b s s A$ and ass $A$ do not necessarily mean that anaerobic aromatic hydrocarbon-degrading microorganisms are absent from the Surui mangrove sediment; they may be present at abundances too low to be detected with the PCR protocol used. Alternatively, anaerobic hydrocarbon degraders possessing ass/bss sequence variants lacking homology to our PCR primers [18] or that employ degradation pathways altogether different to the ones tested here (e.g., carboxylation reactions [32] or the two-step oxidation of methylene observed in the degradation of ethylbenzene by a nitrate-reducing strain [33]) for catabolism of anaerobic hydrocarbons.

PCR-DGGE analyses for $d s r$ showed that the bacterial community profile in the top $5 \mathrm{~cm}$ differs from the two deeper sediment intervals, which was also observed in DGGE analysis of 16S rRNA genes. Nevertheless, the similarities in banding pattern are large concerning sediments of the two deeper layers, while both change a little when comparing to superficial sediment. Similar diversity among dissimilatory sulfite reductase sequences in deeper sediment layers was also observed by Fan and colleagues [34] who analysed $\operatorname{sr} A B$ from the surface to $50 \mathrm{~cm}$ depth. They suggest that different surficial and deeper sediment SRB community structure is related to tidal variation, which makes sediment temporarily oxic, hypoxic or anoxic. Moreover, tidal inundation also transports sulphate from the sea to the coastal sediment, which shows a high sulphate concentration in the first centimetres of sediment, but diluted in the freshwater presents a low concentration downward. Taketani and colleagues [35] also studied SRB community structure using DGGE and showed that SRB diversity decreases with depth in mangrove sediment, as well as revealing a drop in the relative abundance of SRB, in agreement with the qPCR results presented here (Figure 4). However they noted little variation in diversity in the first $30 \mathrm{~cm}$ of that sediment [35]. In anaerobic sediments, SRB play an important role in nutrient cycling and organic matter remineralization [6], and they can be especially important in oilpolluted locations where certain SRB are capable of anaerobic hydrocarbon degradation [11]. Taketani and colleagues confirmed the importance of SRB populations in mangrove sediments, particularly after an oilcontamination event. In a study using mesocosms with pristine and polluted mangrove sediments, they reported an increase in SRB abundance in pristine sediment after oil input, and observed that a mangrove with history of oil contamination is better prepared to respond to such an adverse situation than a non-contaminated one [7].

General bacterial abundance determined by $16 \mathrm{~S}$ rRNAtargeted qPCR was highest in the $0-5 \mathrm{~cm}$ layer sediment, and decreased with depth (Figure 4). The same phenomenon occurs for sulphate-reducing bacteria, in 
agreement with sulphate concentrations measured in the sediment depths investigated. Comparing q-PCR results for $d s r$ and 16S rRNA gene fragment genes suggests that a large fraction of the bacteria present may be sulphatereducers. It is remarkable that in the top sediment, $d s r$ genes represent almost $80 \%$ of the number of genes for general bacteria (16S rRNA gene encoding fragment gene). For the deeper sediments these values are almost $40 \%$ $(15-20 \mathrm{~cm})$ and almost $65 \%(35-40 \mathrm{~cm})$. It is well known that microorganisms contain more than one copy of $16 \mathrm{~S}$ rRNA gene. This also might happen for $d s r$ gene [36]. Moreover, the primers for $16 \mathrm{~S}$ rRNA gene encoding fragment gene used in the present study target bacteria, while in their study, Geets and colleagues [36] also detected archaeal $d s r$ with the same primer pair that was used here. In principle $d s r$ detected in these mangrove sediments by qPCR could have archaeal species, and as such, the values we report could overestimate the number of sulphatereducing bacteria.

This is one of the few studies on anaerobic bacterial diversity in mangrove sediments at different sediment depths. Results presented in this study shows that the bacterial diversity and abundance change with depth. This might explain why petroleum and other xenobiotic compounds that percolate to the deep anoxic sediment layers may remain undegraded for years.

\section{Conclusions}

Sulphate decreases dramatically in the first centimetres of the mangrove sediment, and overall bacterial diversity and abundance from the surficial interval $(0-5 \mathrm{~cm})$ differs from deeper layers $(15-20$ and $35-40 \mathrm{~cm}$ ), which are very similar to each other. Genes involved in anaerobic alkane and aromatic petroleum hydrocarbon degradation were not detected by PCR, perhaps because gene targets for the PCR primers chosen may not have matched to in situ genetic diversity.

\section{Methods}

\section{Sediment sampling}

The sampling site was the Suruí mangrove in Guanabara Bay, situated in Magé, state of Rio de Janeiro, Brazil (Figure 5). In the year 2000, there was an oil spill in Guanabara Bay, impacting the Suruí mangrove. More

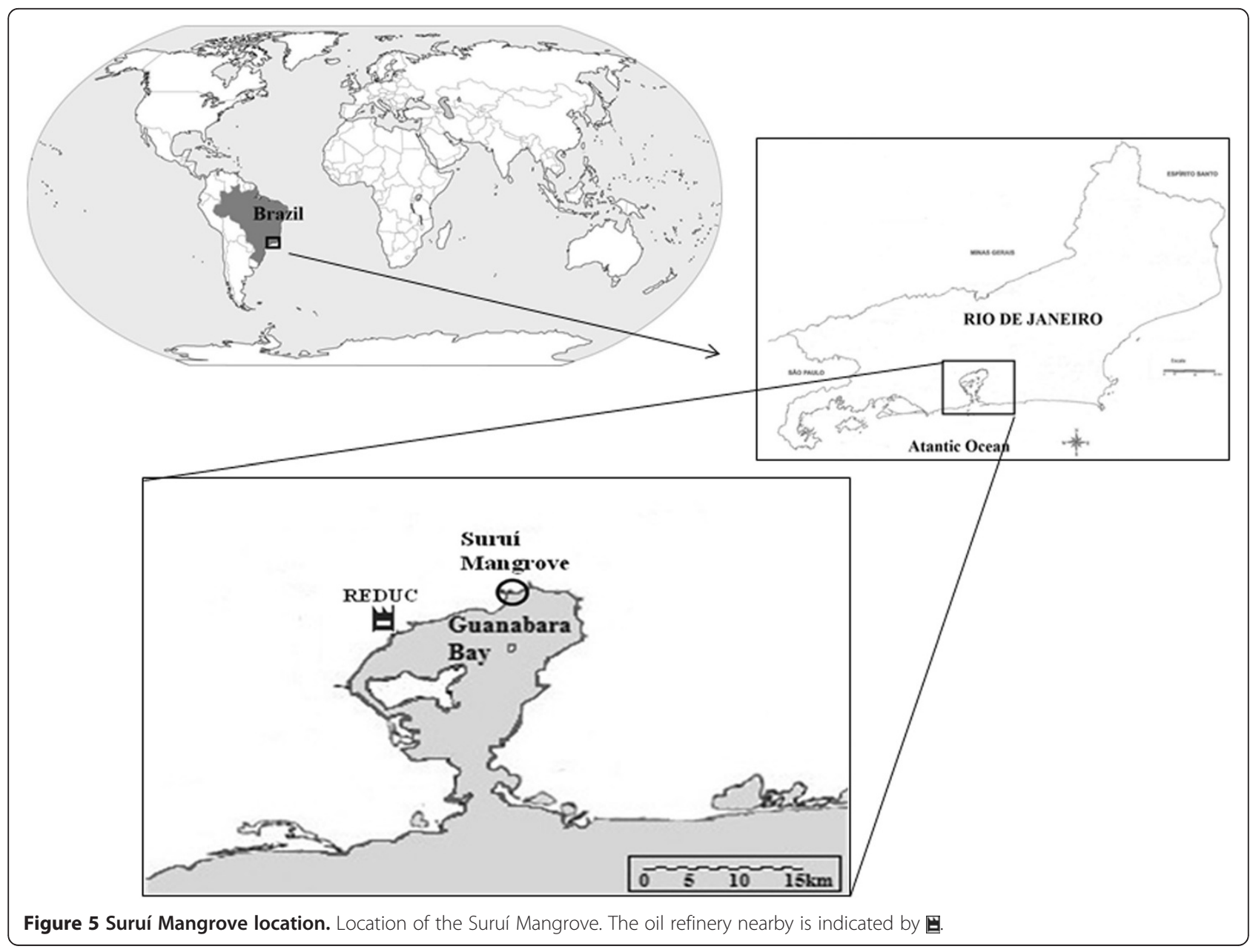


than 1 million liters of oil leaked from a broken pipeline of an oil refinery nearby, and the most affected region was the northern part of the bay [37].

Samples were collected at one point of the mangrove (S $\left.22^{\circ} 41^{\prime} 50^{\prime \prime}, \mathrm{W} 043^{\circ} 07^{\prime} 00^{\prime \prime}\right)$, during the low tide period. Four aluminum tubes $60 \mathrm{~cm}$ in length were used to obtain sediment cores down to $40 \mathrm{~cm}$ depth, with less than $1 \mathrm{~m}$ of distance of each other sampling point. After sampling, tubes were wrapped in plastic material to limit oxygen exposure, and transported immediately to the laboratory for further processing steps.

In the laboratory, each core was sectioned to obtain samples of the following intervals: $0-5,15-20$ and $35-40 \mathrm{~cm}$ deep. Sediment samples of the four replicate cores for each interval were each divided into two parts: a portion reserved for total genomic DNA extraction and molecular based studies, and another one reserved for porewater sulphate analysis.

\section{Sediment porewater sulphate concentration}

Sulphate was analysed by chromatography through Metrohm ion chromatograph with conductivity detection, isolated in a $100 \times 4.0 \mathrm{~mm}$ polyvinyl ethanol column, using sodium carbonate and sodium bicarbonate as eluent.

\section{Molecular techniques for sediment: PCR-DGGE for $16 \mathrm{~S}$ rRNA, bamA and dsr genes}

Total genomic DNA was extracted from bulk sediment of each replicate using FastDNA ${ }^{\circledR}$ SPIN kit, accordingly to manufacturer recommendations.

PCR reactions for further DGGE analysis were performed using U968f-GC1 and L1401, universal primers for the 16S rRNA gene, as previously described by Heuer and Smalla [38]. Before DGGE analysis, PCR products were confirmed to have been amplified by electrophoresis in a $1.2 \%$ agarose gel run at $80 \mathrm{~V}$ in Tris-Borate-EDTA buffer, and further staining step for $15 \mathrm{~min}$ immerse in a solution containing $0.5 \mathrm{~g} / \mathrm{ml}$ ethidium bromide and revealed under short-wavelength ultraviolet light.
PCR products were submitted to DGGE analysis [39] using a DCode System (universal mutation detection system, BioRad, Richmond, USA), using a 6\% acrylamide gel within a denaturing gradient of $40 \%$ to $70 \%$ of a mixture of urea and formamide. Electrophoresis was performed in $1 \mathrm{x}$ Tris-acetate-EDTA buffer at $60^{\circ} \mathrm{C}$ and at $75 \mathrm{~V}$ for $16 \mathrm{~h}$. For the staining step, Sybr Gold (Invitogen) was used, and the gel was visualised using a Storm 860 Imaging System (GE Healthcare). DGGE images were analysed using BioNumerics software (Applied Maths, Belgium) and similarities between lanes were calculated using the band-based Jaccard correlation coefficients, and cluster analysis was performed by the unweighted pair group method with average linkages (UPGMA). PCR-DGGE was also performed for bamA to compare the profile of diversity of anaerobic hydrocarbon-degrading bacteria at the three studied depths. PCR mixture and conditions for the bamA reactions were as previously described by Küntze and colleagues [20]. Primers SP9 and ASP1 were used and PCR products run on a $9 \%$ acrylamide gel within a denaturing gradient of $50 \%$ to $70 \%$ of urea and formamide. To primer SP9 a GC clamp (5'-CGC CCG GGG CGC GCC CCG GGC GGG GCG GGG GCA CGG GGG G-3') was attached to stabilize transition forms of the DNA molecule, improving band pattern results [40].

To compare the diversity of SRB at different depths, a PCR-DGGE was executed using two pairs of primers for $d s r$ gene (Table 1). Formerly, a PCR reaction was carried out using the Primer Set 1 . The resulting amplicons of this reaction became templates for a second PCR reaction using Primer Set 2.

Reaction with Primer Set 1 consisted of a $25 \mu \mathrm{lmix}$ ture, containing $1 \times 100 \mathrm{mM}$ Tris $-\mathrm{HCl}\left(\mathrm{pH} 8.8\right.$ at $\left.25^{\circ} \mathrm{C}\right)$, $500 \mathrm{mM} \mathrm{KCl}, 0.8 \%$ (v/v) Nonidet P40 (Fermentas), $1.75 \mathrm{mM} \mathrm{MgCl}_{2}, 50 \mathrm{mM}$ of each dNTP, $200 \mathrm{nM}$ of each oligonucleotide primer (Set 1), $2.5 \mathrm{U}$ of Taq DNA polymerase (Fermentas), $0.5 \mu \mathrm{l}$ of bovine serum albumin (BSA) $1 \%(\mathrm{~V} / \mathrm{V})$, and $1 \mu \mathrm{l}$ of DNA. Amplification conditions comprised an initial denaturation step of $94^{\circ} \mathrm{C}$ for $5 \mathrm{~min}$, followed by 30 cycles of $94^{\circ} \mathrm{C}$ for $30 \mathrm{~s}, 55^{\circ} \mathrm{C}$ for $30 \mathrm{~s}$ and $72^{\circ} \mathrm{C}$ for $90 \mathrm{~s}$, and a final extension step of $72^{\circ} \mathrm{C}$ for $10 \mathrm{~min}$. PCR with Primer Set 2 consisted of a $50 \mu \mathrm{l}$

Table 1 Primers for sulphate-reducing bacteria detection

\begin{tabular}{cccc}
\hline & Primer Set & Forward $(\mathbf{F})$ and Reverse (R) Oligonucleotide Primer Sequences & Reference \\
\hline Primer Set 1 & DSR1F & F: 5'-ACS CAC TGG AAG CAC GGC GG-3' & [23] \\
DSR4R & R: 5'-GTG TAG CAG TTA CCG CA-3' & [36] \\
Primer Set 2 & DSRp2060F-GC & F: 5'-CGC CCG CCG CGC CCC GCG CCC GGC CCG CCG & [36] \\
& CCC CCG CCC CCA ACA TCG TYC AYA CCC AGG G-3' & [36] \\
\hline
\end{tabular}

Oligonucleotide primers used in PCR reactions for assessment of the sulphate-reducing bacterial communities and comparison between the 3 studied depths. 
mixture, containing $1 \mathrm{x} 100 \mathrm{mM}$ Tris- $\mathrm{HCl}(\mathrm{pH} 8.8$ at $\left.25^{\circ} \mathrm{C}\right), \quad 500 \mathrm{mM} \mathrm{KCl}, 0.8 \%(\mathrm{v} / \mathrm{v})$ Nonidet $\mathrm{P} 40$ (Fermentas), $1.75 \mathrm{mM} \mathrm{MgCl}_{2}, 50 \mathrm{mM}$ of each dNTP, $200 \mathrm{mM}$ of each oligonucleotide primer (Set 2), $2.5 \mathrm{U}$ of Taq DNA polymerase (Fermentas), $0.5 \mu \mathrm{l}$ of bovine serum albumin (BSA) $1 \%(\mathrm{v} / \mathrm{v})$, and $2 \mu \mathrm{l}$ of amplicon from the previous reaction. Amplification conditions comprehended an initial denaturation step of $95^{\circ} \mathrm{C}$ for $5 \mathrm{~min}$, followed by 20 cycles of $95^{\circ} \mathrm{C}$ for $40 \mathrm{~s}, 65$ down to $55^{\circ} \mathrm{C}\left(-0.5^{\circ} \mathrm{C}\right.$ at each cycle $)$ for $1 \mathrm{~min}$ and $72^{\circ} \mathrm{C}$ for $1 \mathrm{~min}, 20$ cycles of $94^{\circ} \mathrm{C}$ for $40 \mathrm{~s}, 55^{\circ} \mathrm{C}$ for $40 \mathrm{~s}$ and $72^{\circ} \mathrm{C}$ for $1 \mathrm{~min}$, and a final extension step of $72^{\circ} \mathrm{C}$ for $5 \mathrm{~min}$. Amplification success was confirmed with electrophoresis on agarose gel $1.2 \%(\mathrm{~m} / \mathrm{v})$ in TBE buffer $0.5 \mathrm{x}$ at $90 \mathrm{~V}$ for $90 \mathrm{~min}$. Gel was stained in a solution of GelRedT ${ }^{\mathrm{TM}} 1 \mathrm{x}$ (Biotium, CA, USA). PCR products of the second reaction were separated based on GC composition by DGGE analysis, using $9 \%$ acrylamide gel within a denaturing gradient of $45 \%$ to $65 \%$ of urea and formamide.

\section{Molecular techniques for bulk sediment: PCR for ass $A$ and $b s s A$}

To assess the presence of potential anaerobic hydrocarbon degraders at the mangrove, bulk sediment of the three studied depths were submitted to PCR targeting the genes responsible for anaerobic alkane degradation, and anaerobic toluene and xylene degradation. For these the oligonucleotide primers used were assA $2 F / R$ (Aitken et al., unpublished observations) and bssA [22] (Table 2). PCR mixture for assA $2 \mathrm{~F} / \mathrm{R}$ consisted of a $50 \mu \mathrm{l}$ mixture, containing $5 \mu \mathrm{l}$ of $10 \mathrm{x}$ buffer, $1.5 \mathrm{mM} \mathrm{MgCl}_{2}, 0.2 \mathrm{mM} \mathrm{dNTP}$, $0.2 \mu \mathrm{M}$ of each primer, and $1 \mathrm{U}$ of Taq DNA polymerase (Promega), and $1 \mu \mathrm{l}$ of the template DNA. Amplification conditions included an initial denaturation step of $95^{\circ} \mathrm{C}$ for $5 \mathrm{~min}$, followed by 35 cycles of $94^{\circ} \mathrm{C}$ for $1 \mathrm{~min}, 56^{\circ} \mathrm{C}$ for $1 \mathrm{~min}$ and $72^{\circ} \mathrm{C}$ for $1 \mathrm{~min}$, and a final extension step of $72^{\circ} \mathrm{C}$ for $5 \mathrm{~min}$. PCR mixture and conditions for $b s s A$ followed what was previously described elsewhere [23].

\section{Molecular techniques for bulk sediment: q-PCR for $16 \mathrm{~S}$ rRNA and $d s r$ genes}

Quantitative PCR (q-PCR) assays were carried out using ABIPrism 7500 (Applied Biosystems) detection system, to quantify abundance of the gene encoding the $16 \mathrm{~S}$ rRNA, following manufacturer's recommendations.

Amplification consisted of a $25 \mu \mathrm{l}$ reaction containing $12.5 \mu$ l of GoTaq ${ }^{\circledR}$ q-PCR Master Mix 2x (Promega), $40 \mathrm{mM}$ Tris- $\mathrm{HCl}$ (pH 8.4), $100 \mathrm{mM} \mathrm{KCl.} 6 \mathrm{mM} \mathrm{MgCl}_{2}$, $400 \mu \mathrm{M}$ dATP, $400 \mu \mathrm{M}$ dCTP, $400 \mu \mathrm{M}$ dGTP, $800 \mu \mathrm{M}$ dUTP, $40 \mathrm{U} / \mathrm{ml}$ UDG (Invitrogen), $200 \mathrm{nM}$ of each primer, $0.5 \mu \mathrm{l}$ ROX Reference Dye $50 \mathrm{mM}$ (Invitrogen), $0.5 \mu \mathrm{l}$ BSA ( $1 \mathrm{mg} / \mathrm{ml}), 5.5 \mu \mathrm{l} \mathrm{H}_{2} \mathrm{O}$ and $2 \mathrm{ng}$ DNA. Oligonucleotide primers used were $357 \mathrm{~F}$ (5'-CTA CGG GRS GCA G-3') and 529R (5'-CGC GGC TGC TGG CAG-3'), modified from Muyzer and colleagues [39]. The assays were performed in triplicates. A standard DNA sample was previously used to make a standard curve, and $\mathrm{H}_{2} \mathrm{O}$ was used as the negative control. PCR conditions consisted of an initial denaturation step of $94^{\circ} \mathrm{C}$ for $3 \mathrm{~min}$, followed by $30-40$ cycles of $95^{\circ} \mathrm{C}$ for $1 \mathrm{~min}, 55^{\circ} \mathrm{C}$ for $1 \mathrm{~min}$ and $72^{\circ} \mathrm{C}$ for $45 \mathrm{~s}$.

A q-PCR was also used to quantify SRB population, with ABIPrism 7500 (Applied Biosystems) detection system, to quantify abundance of the gene dsr. Amplification step was carried out with a $25 \mu \mathrm{l}$ mixture containing $12.5 \mu \mathrm{l}$ of GoTaq ${ }^{\circledR}$ q-PCR Master Mix 2x (Promega), $0.5 \mu \mathrm{l}$ of each primer $10 \mu \mathrm{M}$, $0.5 \mu \mathrm{BSA}(1 \mathrm{mg} / \mathrm{ml}), 4.5 \mu \mathrm{l} \mathrm{H}_{2} \mathrm{O}$ and $2 \mathrm{ng}$ DNA [41]. Oligonucleotide primers used were DSR1F (5'ACS CAC TGG AAG CAC GGC GG-3') and DSR-R (5'-GTG GMR CCG TGC AKR TTG G-3') [23]. PCR conditions consisted of an initial denaturation step of $95^{\circ} \mathrm{C}$ for $5 \mathrm{~min}, 35$ cycles of $95^{\circ} \mathrm{C}$ for $1 \mathrm{~min}, 57^{\circ} \mathrm{C}$ for $1 \mathrm{~min}$ and $72^{\circ} \mathrm{C}$ for $45 \mathrm{~s}$. All samples were used in triplicates and $\mathrm{H}_{2} \mathrm{O}$ was used as the negative control.

To both reactions (16S rRNA and $d s r$ gene) efficiencies and melting curves were determined and analysed using ABIPrism 7500 Detection System (Applied Biosystems).

Table 2 Primers for anaerobic hydrocarbon degradation genes detection

\begin{tabular}{|c|c|c|c|}
\hline Primer Set & $\begin{array}{c}\text { Forward (F) and Reverse (R) } \\
\text { Oligonucleotide Primer Sequences }\end{array}$ & Expected amplicon size (bp) & Reference \\
\hline \multirow[t]{2}{*}{ SP9/ASP1 (bamA) } & F: 5'-CAG TAC AAY TCC TAC ACV ACB G-3’ & $\sim 300$ & [20] \\
\hline & R: $5^{\prime}-C$ MAT GCC GAT YTC CTG RC-3’ & & \\
\hline \multirow[t]{2}{*}{$\operatorname{ass} A 2 F / R(\operatorname{ass} A)$} & F: 5'-YAT GWA CTG GCA CGG MCA-3' & 440 & Aitken et al., unpublished observations \\
\hline & R: 5'-GCR TाT TCM ACC CAK GTA-3' & & \\
\hline \multirow[t]{2}{*}{7772 F/8546R (bssA) } & F: 5'-GAC ATG ACC GAC GCS ATY CT-3' & $\sim 794$ & [22] \\
\hline & R: 5'-TCG TCG TCR TTG CCC CAY TT-3' & & \\
\hline
\end{tabular}




\section{Abbreviations}

BSA: Bovine serum albumin; DGGE: Denaturing gradient gel electrophoresis; PCR: Polymerase chain reaction; PRAS: Pre-reduced anaerobic sterilized; q-PCR: Quantitative polymerase chain reaction; SRB: Sulphate reducing bacteria; UPGMA: Unweighted pair group method with average.

\section{Authors' contributions}

LLA conceived of the study, and participated in its design and coordination and wrote the manuscript. DCAL carried out some of the molecular genetic studies. EMF helped with sampling and processing steps. LQF and GRP helped with anaerobic manipulation of samples and design of the experiments. MJM participated in the data interpretation. $\mathrm{CH}$ participated in the data interpretation and writing. RSP helped in the experiment design, data interpretation and wrote the manuscript. RMCPD and ASR were the major responsible by the experiment design, and helped in data interpretation and wrote the manuscript. All authors read and approved the final manuscript.

\section{Acknowledgements}

This work was funded by Conselho Nacional de Desenvolvimento Científico e Tecnológico (CNPq), Petrobras and Fundação de Amparo à Pesquisa do Estado do Rio de Janeiro (FAPERJ), and a grant from Coordenação de Aperfeiçoamento de Pessoal de Nível Superior (CAPES). The authors also would like to thank Prof. lan Head for helping with data interpretation and Sandro Lessa Andrade for have provided Suruí mangrove map for this study.

\section{Author details}

${ }^{1}$ Laboratório de Ecologia Molecular Microbiana, Instituto de Microbiologia Paulo de Góes, Universidade Federal do Rio de Janeiro, Rio de Janeiro, Brazil. ${ }^{2}$ Laboratório de Biologia de Anaeróbios, Instituto de Microbiologia Paulo de Góes, Universidade Federal do Rio de Janeiro, Rio de Janeiro, Brazil. ${ }^{3}$ School of Civil Engineering and Geosciences, Newcastle University, Newcastle upon Tyne, UK.

Received: 29 January 2012 Accepted: 23 August 2012

Published: 30 August 2012

\section{References}

1. Merhi ZO: Gulf Coast oil disaster: impact on human reproduction. Fertil Steril 2010, 94:1575-1577.

2. Mitsch WJ: The 2010 oil spill in the Gulf of Mexico: What would Mother Nature do? Ecological Engineering 2010, 36:1607-1610.

3. Head IM, Jones DM, Röling WFM: Marine microorganisms make a meal of oil. Nat Rev Microbiol 2006, 4:173-182.

4. Olguín EJ, Hernández ME, Sánchez-Galván G: Contaminación de manglares por hidrocarburos y estratégias de biorremediación, fitorremediación y restauración. Ver Int Contam Ambient 2007, 23:139-154.

5. Dias ACF, Andreote FD, Rigonato J, Fiore MF, Melo IS, Araújo WL: The bacterial diversity in a Brazilian non-disturbed mangrove sediment. Antonie van Leeuwenhoeck 2010, 98:541-551.

6. Lyimo TJ, Pol A, Harhangi HR, Jetten MSM, den Camp HJMO: Anaerobic oxidation of dimethylsulçde andmethanethiol in mangrove sediments is dominated by sulfate-reducing bacteria. FEMS Microbiol Ecol 2009, 70: 483-492.

7. Taketani RG, Franco NO, Rosado AS, van Elsas JD: Microbial community response to a simulated hydrocarbon spill in mangrove sediments. J Microbiol 2010, 48:7-15.

8. Li C-H, Zhou H-W, Wong Y-S, Tam NF-Y: Vertical distribution and anaerobic biodegradation of polycyclic aromatic hydrocarbons in mangrove sediments in Hong Kong, South China. Sci Total Environ 2009, 407:5772-5779.

9. Burns KA, Codi S: Contrasting impacts of localised versus catastrophic oil spills in mangrove sediments. Mangroves and Salt Marshes 1998, 2:63-74.

10. Ke L, Yu KSH, Wong YS, Tam NFY: Spatial and vertical distribution of polycyclic aromatic hydrocarbons in mangrove sediments. Sci Total Environ 2005, 340:177-187.

11. Widdel F, Knittel K, Galushko A: Anaerobic hydrocarbon-degrading microorganisms: an overview. In Handbook of hydrocarbon and lipid microbiology. Edited by Timmis KN. Germany: Springer-Verlag Berlin Heidelberg; 2010:1997-2022.
12. Boopathy R: Anaerobic degradation of No. 2 diesel fuel in the wetland sediments of Barataria-Terrebonne estuary under various electron acceptor conditions. Biores Technol 2003, 86:171-175.

13. Boopathy R: Anaerobic biodegradation of no. 2 diesel fuel in soil: a soil comumn study. Biores Technol 2004, 94:143-151.

14. Boopathy R, Shields S, Nunna S: Biodegradation of crude oil from the BP oil spill in the marsh sediments of Southeast Louisiana, USA. Appl Biochem Biotechnol 2012, http://dx.doi.org/10.1007/s12010-012-9603-1.

15. Rabus R, Jarling R, Lahme $S$, Kühner $S$, Heider J, Widdel F, Wilkes $H$ : Co-metabolic conversion of toluene in anaerobic $n$-alkane degrading bacteria. Environ Microbiol 2011, 13:2576-2586.

16. Grossi V, Cravo-Laureau C, Guyoneaud R, Ranchou-Peyruse A, Hirschler-Réa A: Metabolism of $n$-alkanes by anaerobic bacteria: a summary. Org Geochem 2008, 39:1197-1203.

17. Callaghan AV, Warwik B, Chadain SMN, Young LY, Zylstra GJ: Anaerobic alkane-degrading strain AK-01 contains two alkylsuccinate synthase genes. Biochem Bioph Res Commun 2008, 366:142-148.

18. Callaghan AV, Davidova IA, Savage-Ashlock K, Parisi VA, Gieg LM, Suflita JM, Kukor JJ, Wawrik B: Diversity of benyzl- and alkylsuccinate synthase genes in hydrocarbon-impacted environments and enrichment cultures. Environ Sci Technol 2010, 44:7287-7294.

19. Heider J, Fuchs G: Anaerobic metabolism of aromatic compounds. Eur J Biochem 1997, 243:577-596.

20. Küntze K, Shinoda Y, Moutakki H, Mclnerney MJ, Vogt C, Richnow H, Boll M: 6-Oxocyclohex-1-ene-1-carbonyl-coenzyme A hydrolases from obligately anaerobic bacteria: characterization and identification of its gene as a functional marker for aromatic compounds degrading anaerobes. Environ Microbiol 2008, 10:1547-1556.

21. Beller HR, Kane SR, Legler TC, Alvarez PJJ: A real-time polymerase chain reaction method for monitoring anaerobic hydrocarbon-degrading bacteria based on a catabolic gene. Environ Sci Technol 2002, 32:3977-3984

22. Winderl C, Schaefer S, Lueders T: Detection of anaerobic toluene and hydrocarbon degraders in contaminated aquifers using benzylsuccinate synthase (bssA) genes as a functional marker. Environ Microbiol 2007 9:1035-1046.

23. Kondo J, Nedwell DB, Purdy KJ, Silva SQ: Detection and enumeration of sulphate-reducing bacteria in estuarine sediments by competitive PCR Geomicrobiol J 2004, 21:145-157.

24. Macdonald BCT, Smith J, Keene AF, Tunks M, Kinsela A, White I: Impacts of runoff from sulfuric soils on sediment chemistry in an estuarine lake. SC Total Environ 2004, 329:115-130.

25. Leloup J, Loy A, Knab NJ, Borowski C, Wagner M, Jørgensen BB: Diversity and abundance of sulfate-reducing microorganisms in the sulfate and methane zones of a marine sediment, Black Sea. Environ Microbiol 2007, 9:131-142.

26. Leloup J, Fossing $H$, Kohls $K$, Holmkvist $L$, Borowski $C$, Jørgensen BB, Jørgensen BB: Sulfate-reducing bacteria in marine sediment (Aarhus Bay, Denmark): abundance and diversity related to geochemical zonation. Environ Microbiol 2009, 11:1278-1291.

27. Habicht KS, Gade M, Tharndrup B, Berg P, Canfield DE: Calibration of sulphate levels in the Archean Ocean. Science 2002, 298:2372-2374.

28. Chatterjee S, Dickens GR, Bhatnagar G, Chapman WG, Dugan B, Snyder GT, Hirasaki GJ: Pore water sulfate, alkalinity, and carbon isotopes profiles in shallow sediment above marine gas hydrate systems: a numerical modelling perspective. J Geophys Res 2011, 116:B09103. http://dx.doi:10.1029/2011JB008290.

29. Lyimo TJ, Pol A, den Camp HJMO: Sulfate reduction and methanogenesis in sediments of Mtoni mangrove forest, Tanzania. Ambi 2002, 31:614-616.

30. Staats M, Braster M, Röling WFM: Molecular diversity and distribution of aromatic hydrocarbon-degrading anaerobes across a landfill leachate plume. Environ Microbiol 2011, 13:1216-1227.

31. Lahme S, Eberlein C, Jarling R, Kube M, Boll M, Wilkes H, Reinhardt R, Rabus $R$ : Anaerobic degradation of 4-methylbenzoate via a specific 4-methylbenzoyl-CoA pathway. Environ Microbiol 2012, 14:1118-1132.

32. Spormann AM, Widdel F: Metabolism of alkylbenzenes, alkanes, and other hydrocarbons in anaerobic bacteria. Biodegradation 2000, 11:85-105.

33. Rabus R, Heider J: Initial reactions of anaerobic metabolism of alkylbenzenes in denitrifying and sulfate-reducing bacteria. Arch Microbiol 1998, 170:377-384. 
34. Fan $L-F$, Tang $S-L$, Chen C-P, Hsieh H-L: Diversity and composition of sulfate- and sulfite-reducing prokaryotes as affected by marine freshwater gradient and sulfate availability. Microbiol Aquatic Sys 2011, 63:224-237.

35. Taketani RG, Yoshiura CA, Dias ACF, Andreote FD, Tsai SM: Diversity and identification of methanogenic archaea and sulphate-reducing bacteria in sediments from a pristine tropical mangrove. Antonie van Leeuwenhoeck 2010, 97:401-411.

36. Geets J, Borremans B, Diels L, Springael D, Vangronsveld J, Lelie D, Vanbroekhoven K: DsrB gene-based DGGE for community and diversity surveys of sulphate-reducing bacteria. J Microbiol Methods 2006, 66:194-205.

37. Michel J: Assessment and recommendations for the oil spill cleanup of Guanabara Bay, Brazil. Spill Sci Technol Bull 2000, 6:89-96.

38. Heuer $\mathrm{H}$, Smalla K: Application of denaturing gradient gel electrophoresis (DGGE) and temperature gradient gel electrophoresis for studying soil microbial communities. In Modern Soil Microbiology. Edited by van Elsas JD, Trevors J, Wellington EMH. New York: Marcel Dekker; 1997:353-373.

39. Muyzer G, De Waal EC, Uitterlinden AG: Profiling of complex microbial populations by denaturing gradient gel electrophoresis analysis of polymerase chain reaction-amplified genes coding for 16S rRNA. Appl Environ Microbiol 1993, 59:695-700.

40. Rosado AS, Duarte GF: Utilização de eletroforese em gel com gradiente de desnaturantes (DGGE) e gel com gradiente de temperatura (TGGE) para estudar a diversidade microbiana. In Genética e melhoramento de microrganismos. Edited by de Mello IS, Valadares-Inglis MC, Nass LL, Valois ACC. Jaguariúna: Embrapa Meio Ambiente; 2002:97-128.

41. Spence C, Whitehead TR, Cotta MA: Development and comparison of SYBR Green quantitative real-time PCR assays for detection and enumeration of sulfate-reducing bacteria in stored swine manure. J Appl Microbiol 2008, 105:2143-2152.

doi:10.1186/1471-2180-12-186

Cite this article as: Andrade et al:: Microbial diversity and anaerobic hydrocarbon degradation potential in an oil-contaminated mangrove sediment. BMC Microbiology 2012 12:186.

\section{Submit your next manuscript to BioMed Central and take full advantage of:}

- Convenient online submission

- Thorough peer review

- No space constraints or color figure charges

- Immediate publication on acceptance

- Inclusion in PubMed, CAS, Scopus and Google Scholar

- Research which is freely available for redistribution 